\title{
MODELLING THE NEO-INDUSTRIALIZATION STRATEGY AS A MECHANISM OF INNOVATIVE ACTIVITY OF INDUSTRIAL BUSINESS
}

\author{
Dladimir V. Klimuk ${ }^{1}$, Associate professor Ph.D.; \\ D Andrejs Lazdins ${ }^{2}$, Assistant professor Dr.oec. \\ ${ }^{1}$ Baranovichi State University, Republic of Belarus; ${ }^{2}$ Latvia University of Life Sciences \\ and Technologies
}

\begin{abstract}
Research goal: discover the importance of the innovation process in the context of education - science and production. Research tasks: describe the theoretical elements of the innovation process in relation to the Belarusian experience; to develop a model of innovation implementation science - education - production. Research methods: methods of situation description and process systematics were used in the research; statistical and modelling method of data. The most important competitive advantage of industrial enterprises, especially in the current situation - the coronavirus crisis, are innovations formed in the product concept, technological vector, management tactics and the general strategy of the organization. To bring an idea to the market requires its detailed feasibility study, testing, commercialization, scaling, and re-innovation. Successfully passed the stages of approbation and implementation of new innovations create a basic complex of competitive advantages of the industry, and its new orts of development. The role of scientific and educational potential, the introduction of a cooperative model of resource use to achieve economic and social effect has been determined. The paper proposes a toolkit for assessing the effectiveness of a neo-industrialization strategy in the direction of enhancing the innovative activity of industrial business entities, analysing the calculated results, including using the proposed visualization toolkit. Types of neo-industrialization strategies with a set of key components of the impact on the level of development of the sector are presented. Research innovation: a stage model for the introduction of useful innovations from science - education to production has been developed.
\end{abstract}

Key words: innovation; neo-industrialization; strategy; assessment toolkit.

JEL code: 030

\section{Introduction}

In the context of global trends and national development priorities, the task of national policies is to create the necessary preconditions - human capital, knowledge, skills and competences, technology - to ensure quality education and skills, social and economic prosperity and security, quality of life and transition to a climate-neutral economy.

Scientific and educational organizations are the main generator of innovative ideas. The challenge in these commercialisation-related activities is that they must simultaneously consider the processes of generating innovations, developing products and services based on these processes and then forming a business model around the product-service system [5]. The most important problem in creating innovations is the low level of their commercialization, which is due to several reasons:

- low level of market analysis (market supply and demand, competition, promotion system and other components);

- insufficient level of innovation (originality) of the offered product;

- external risk factors;

- a narrow range of financing instruments (investment proposals).

Research goal - discover the importance of the innovation process in the context of education - science and production. Research tasks: 1. Describe the theoretical elements of the innovation process in relation to the Belarusian experience. 2. To develop a model of innovation implementation science - education production. Research methods: Methods of situation description and process systematics were used in 
the research; statistical and modelling method of data. Research innovation: A stage model for the introduction of useful innovations from science - education to production has been developed.

\section{Research results and discussion}

The problematic issues that are currently being formed in the scientific and educational system related to the digital transformation of the economy and the labour market, the development of distance employment, resistance from teachers to the introduction of digital technologies, the limitation of budgetary resources, the impossibility of implementing international mobility, make it necessary to initiate new and activate existing partnerships. This will make it possible to implement the principle of cooperation of benefits, ensuring the pooling of intellectual resources, investment, material and technical (Collaborative Mechanisms for ..., 2011).

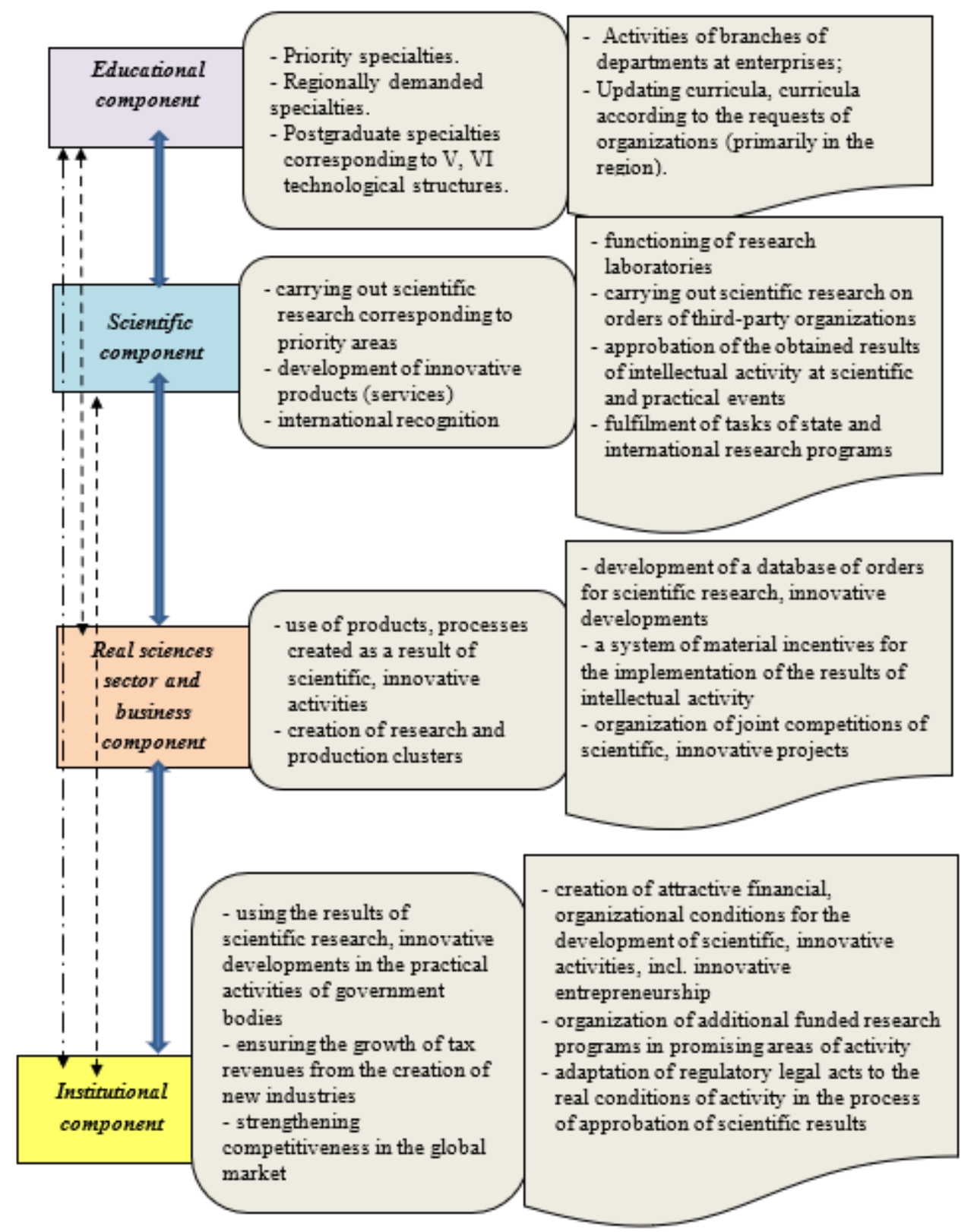

Source: author's calculations based on Klimuk V. V., Chernova O. A., Lazdins A.

Fig. 1. The cooperative model of the development of the innovative potential of the region (Klimuk, V. V., Chernova, O. A., Lazdins, A., 2020) 
As a result of the implementation of the model of collaboration of agents interested in the development of the innovative potential of the region - on the basis of the cooperation of the resources of educational organizations, opportunities open up in the direction of generating joint innovative ideas, obtaining additional sources of funding, forming a new and strengthening existing project teams, sharing elements of material and technical infrastructure and other vectors of interaction (Klimuk, V. V., 2017; Terziev, V., Andreeva, O., Georgiev, M., Klimuk, V. V., 2020).

However, in this process of combining, only the resources of the educational organizations themselves are not enough, since the final product must be delivered to the recipient, which, in turn, requires attracting investors in order to form the necessary financial resources for conducting procurement operations, organizations of the real sector of the economy and business to form actual product requests, authorities to assess the priority, the need for specific product segments for the region (country) (Pecherskaya, E. P., Klimuk, V. V., Tarasova, T. M., 2019; Collaborative Mechanisms for ..., 2011; Terziev, V., Georgiev, M., Klimuk, V., 2020).

Thus, the main challenge of most national economies is the need for balanced interaction between subjects of scientific and innovation systems, economic entities and businesses, authorities in regions and countries (Fig. 1).

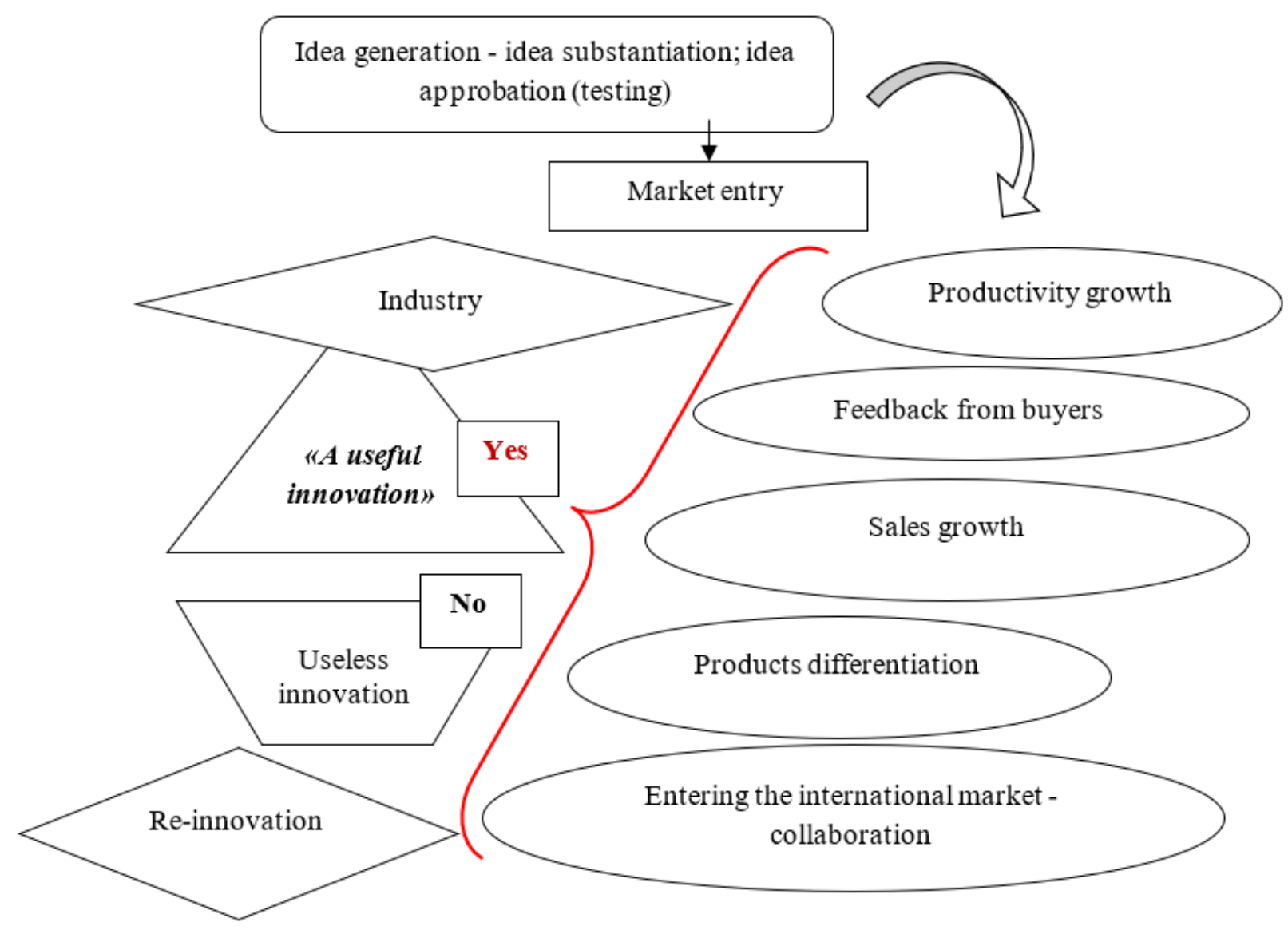

\section{Source: developed by the authors}

Fig. 2. Step-by-step process of creating a "useful" innovation

State industry is one of the main economic development sectors. The product and process innovation model forms a new ort for industrial development: neo-industrialisation, which is characterized only using new technologies aimed at "useful innovation" (Fig. 2):

- in product and service production processes - to improve products or services; 
- in management processes - to improve the efficiency of the management system (decision, planning, organisation, motivation, control).

For the development of the process, making quality decisions regarding the necessary adjustments, it is imperative to evaluate the activities in the area under study. To assess the effectiveness of the implementation of neo-industrialization, a system of the following new indicators is proposed.

1) The rate of change in the share of innovative products in the total volume of industrial production.

2) The rate of change in the volume of production of innovative industrial products.

3) The rate of change in the volume of investments in the industrial sector.

4) The rate of change in the share of employed workers performing research and development in the industrial sector in the total number of employed in industry.

5) The rate of change in the volume of production of "latest" technological modes.

6) The new ratio of the rate of change in the volume of production of innovative industrial products to the rate of change in growth domestic product (GDP).

7) The new ratio of the rate of change in the volume of exports of innovative industrial products to the rate of change in the volume of imports of this product (Terziev, V., Georgiev, M., Klimuk, V., 2020; Klimuk, V. V., 2015).

The complex of these indicators determines the estimated characteristic of the industrial sector's efficiency, which indicates the implementation of a "new" normality in the ort of the country's industrial development - neo-industrialization, or the established model of industrial activity.

The indicators of the system characterize the dynamics of production and management processes in industry and indicate the dynamics in the studied area - the formation of neo-industrialization - with a positive change in the quantitative index (Terziev, V., Georgiev, M., Klimuk, V., 2020).

To test the proposed assessment methodology, calculations were performed in a comparative analysis of the Republic of Belarus. 


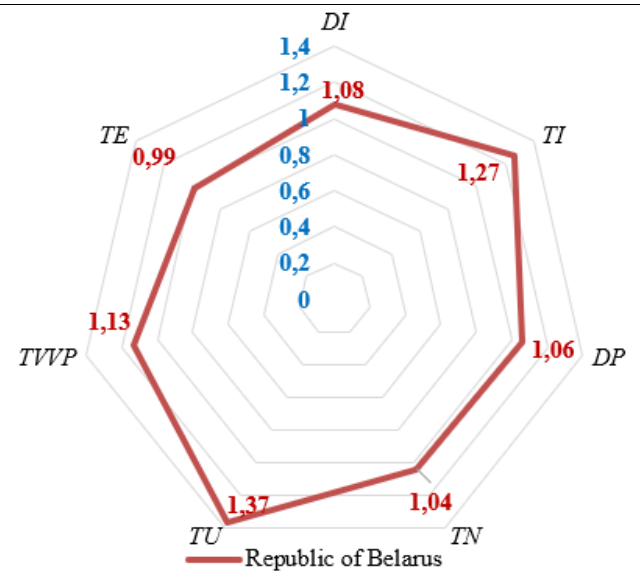

Where:

DI - is the rate of change in the share of innovative products in the total volume of industrial production;

TI - is the rate of change in the volume of production of innovative industrial products;

DP - the rate of change in the volume of investments in the industrial sector;

TN - is the rate of change in the share of employed workers performing research and development in the industrial sector in the total number of employed in industry;

TU - is the rate of change in the volume of production of the "latest" technological modes;

TVVP - is the ratio of the rate of change in the volume of production of innovative industrial products to the rate of change in gross domestic product;

TE - is the ratio of the rate of change in the volume of exports of innovative industrial products to the rate of change in the volume of imports of this product.

\section{Source: developed based on the National Statistical Committee of the Republic of Belarus}

\section{Fig. 3. Component vectors of neo-industrialization according to the data of the Republic of Belarus for 2019}

To visualize the results of calculations, it is proposed to use the ort diagram that clearly reflects the current and changing state of the proposed indicators, which, as a result, allows you to quickly make decisions regarding adjustments to management, production processes based on identified bottlenecks (Fig. 3).

Thus, the innovative development of the country's industrial sector is characterized by positive dynamics in 2019 - by $7.8 \%$.

The emphasis in the analysis should be made on a significant increase in the production of industrial products based on new, high ("breakthrough") technologies (Nacionalnij statisticeskij komitet ..., 2020).

The following should be noted as "weak points" in the direction of neo-industrialization:

- an indicator of the number of involved labour resources engaged in research and innovative development;

- excess of import of innovations over export.

To solve the first problematic task, it is necessary to strongly stimulate research and innovation among the personnel of industrial organizations. The following incentives are offered as new incentive tools: rating point system of remuneration of employees; organization of joint fundamental, applied scientific research; bonuses for scalability, export orientation, search for potential new market.

To solve the second problematic task, it is necessary to implement the direction of cooperation of scientific organizations (universities), organizations of the industrial sector (their research departments) to form a research and production cluster, realizing the principle of synergy of results of activities, and consider the possibility of creating joint international research and production (network) alliances aimed at the production of products technological orders (Fig. 4). 
The structure of labor

resources engaged in scientific and innovative activities

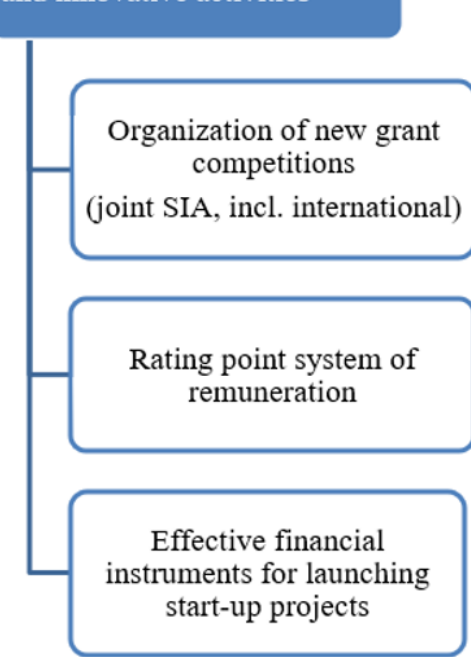

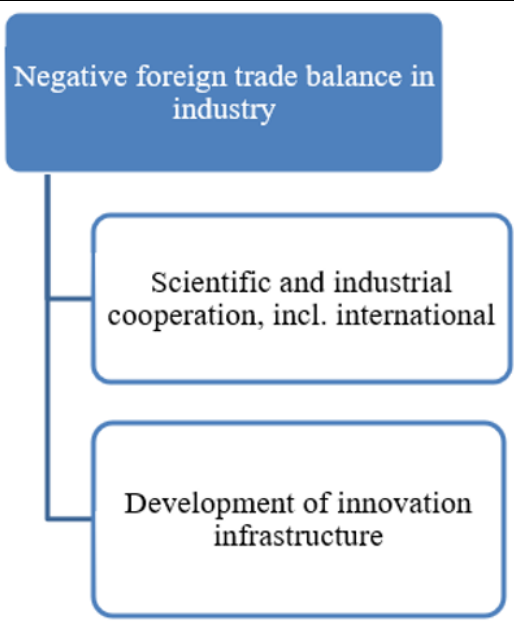

\section{Source: developed by the authors}

\section{Fig. 4. Directions for enhancing innovation in industry}

The implementation of the orts of neo-industrialization can be carried out based on a collaboration strategy due to the cooperation of partners of the scientific and production ecosystem (scientific and educational organizations; the real sector of the economy; business; authorities; public organizations). This will strengthen innovation policy by focusing on the development of a new innovation platform (which forms the basis of the new innovation infrastructure), the gradual introduction of innovation, and the intensification (cooperation) of research and deployment based on improving organizational mechanisms to stimulate the development of industrial business.

The establishment of an effectively coordinated and integrated knowledge and technology transfer system is necessary to:

1) promote the exchange of ideas, skills, competences, experiences and data, mutual learning and the strengthening of innovation capacity;

2) promote the invention of new knowledge-intensive technologies and the creation of innovative products and services with higher added value that are competitive in international markets;

3) stimulate purposeful development and implementation of technological and social, digital, and ecoinnovations in industrial or public administration processes.

4) The development and availability of an open, secure, and interoperable public data infrastructure for research and innovation is essential for the establishment of an efficient knowledge and technology transfer system. Clearly, the transformation of traditional economic sectors in the regions towards greater resource efficiency and productivity, the creation of higher value-added products and services, as well as the development of technologically intensive, internationally competitive innovations.

\section{Conclusions, proposals, recommendations}

1) The current situation (2020 - 2021) requires the development of new knowledge, introduction of new technologies and communication opportunities in the country and in the international environment to promote the implementation of science and innovation.

2) The analysis of the development of the innovation process in the Republic of Belarus reveals that the biggest obstacle to the successful implementation of innovations in production is the insufficient knowledge of employees (low level of education) about innovations and their implementation. 
3) The development of production requires an increase in productivity, an increase in the production of innovative products, the promotion of the development of sectoral innovations, an increase in the level of knowledge of those working in production to promote innovative processes.

4) To promote the introduction of innovations in production, motivating elements must be used, which would promote the acquisition of new knowledge, create the need to work on the implementation of new technologies, products, organizational forms. Cooperation between scientists, universities and manufacturing companies is important for a successful innovation process, where a common position is formed - the innovation ecosystem.

\section{Bibliography}

1. Collaborative Mechanisms for Intellectual Property Management in the Life Sciences. (2011). Retrieved: http://www.oecd.org/sti/emerging-tech/48665248.pdf. Access: 20.12.2020.

2. Klimuk, V.V., Chernova, O.A., Lazdins, A. (2020). Four-link Spiral Model in the Concept of "Smart Specialization" Innovative Industrial Development / RURAL SUSTAINABILITY RESEARCH 2020, VOLUME 43 (338). - 2020. - pp. 52-59. ISSN-2256-0939.

3. Klimuk, V.V., (2015). Pazvitie instrumentarija ocenki efektivnosti izpolzevanija materialinih resursov promisInova predpriatija // Disertacija na soisk uc. Step. Kand. Ekonom. Nauk. - Rostov-na-Donu, 2015. $22 \mathrm{c}$.

4. Klimuk, V. V. (2017). Sirjevaja ekonomika v imperativah neoindustralizacii: monografija. Baranovici, 2017. $272 \mathrm{~s}$.

5. Mikko, P., Jukka, H., Mika, I. (2018). Innovation Commercialisation: Processes, Tools and Implications. Retrieved: https://lutpub.lut.fi/handle/10024/159870 Access:24.12.2020.

6. Nacionalnij statisticeskij komitet Respubliki Belaruss. - Retrieved: https://www.belstat.gov.by. - Access: 29.07.2020.

7. Pecherskaya, E.P., Klimuk, V.V., Tarasova, T.M. (2019). Analysis of European Approaches to Improving the Life of the Population Through the Implementation of a Mechanism of Independent Assessment of Qualifications. Sustainable Growth and Development of Economic Systems. Contradictions in the Era of Digitalization and Globalization. Pages 249-257.

8. Terziev, V., Georgiev, M., Klimuk, V. (2020) PRACTICAL APPLICATION OF THE BALANCED SCORECARD MODEL TO IMPROVE MANAGEMENT OF INTANGIBLE ASSETS / "19th RSEP International Economics, Finance \& Business Conference" organized by Review of Socio-Economic Perspectives (RSEP), on 1-2 December 2020 in Prague at Anglo-American University.

9. Terziev, V., Andreeva, O., Georgiev, M., Klimuk, V.V. (2020). DYNAMICS OF SCIENTIFIC RESULTS IN THE HIGHER EDUCATION. - Proceedings of ADVED 2020- 6th International Conference on Advances in Education 56 October 2020. - pp. 335-344. - ISBN: 978-605-06286-0-9 